\title{
Effect of verapamil on systolic time intervals in rabbits
}

K. Singh

\begin{abstract}
Abstrak
Interval waktu sistolik merupakan indikator sensitif fungsi miokard. Penelitian ini bertujuan untuk menilai kinerja ventrikel kiri sebelum dan sesudah pemberian verapamil i.v. pada kelinci. Elektrokardiogram, fonokardiogram, denyut a.karotid, dan tekanan darah arteri dicatat. Penurunan sistolik elektromekanik, peningkatan waktu curah ventrikel kiri, penurunan waktu pra-curah dan perbandingan PEP/LVET sesudah pemberian verapamil menunjukkan peningkatan kinerja ventrikel, walaupun terdapat penurunan denyut jantung dan penurunan tekanan darah. Hal ini merupakan dasar penggunaan penghambat kanal kalsium pada penyakit-penyakit jantung.
\end{abstract}

\begin{abstract}
Systolic time intervals (STI) are sensitive indices of myocardial function. The present study was conducted to evaluate left ventricular ( $L V)$ performance before and after administration of calcium channel blocker-verapamil (intravenously) in rabbits. Electrocardiogram, phonocardiogram, carotid arterial pulse, and mean arterial blood pressure were recorded. Reduction in electro mechanical systole $\left(Q S_{2}\right)$ rise in left ventricular ejection time (LVET), reduction in pre-ejection period (PEP) and ratio of $P E P / L V E T$ after verapamil administration showed enhanced ventricular performance, although it causes decrease in heart rate and fall in blood pressure. That forms the basis of use of the calcium blockers in cardiac diseases.
\end{abstract}

Keywords : myocardium, calcium blockers, systole

The ability of calcium antagonists to block calcium mediated electromechanical coupling in contractile tissue can produce arterial dilatation in both coronary and peripheral vascular bed. While inhibition of transmembrane cellular flow of calcium during the slow inward current produces favorable electrophysiologic effects. ${ }^{1}$ Calcium antagonists have been shown to have negative inotropic and negative chronotropic effect but at the same time they are advocated for the treatment of various cardiovascular diseases i.e. coronary artery diseases, hypertension and cardiomyopathy. Systolic time intervals (STIs) is sensitive and noninvasive method for assessment of left ventricular (LV) functions. It was, therefore, decided to study the time course of STI changes after administration of commonly used calcium channel blocker (CCB) i.e. verapamil in anesthetized rabbits.

\section{MATERIAL AND METHODS}

The study was carried out in rabbits $(n=18)$ of either sex weighing one to two kilogram (mean 1,96 \pm .6 ).

Department of Physiology, Pt B.D. Sharma Post graduate Institute of Medical Sciences, Rohtak, 124001, Haryana, India
Animal was anesthetized with urethane $(0.5$ to $1 \mathrm{gm} / \mathrm{kg}$ body weight). After tracheal intubation, the right femoral artery was cannulated and connected to pressure transduces (Strain gauge type), which in turn was connected to two channel polyrite to record the mean arterial blood pressure (MAP). Electro cardiogram (ECG), carotid arterial pulse (CAP) and phonocardiogram (PCG) were recorded simultaneously on four channel polyrite (INCO). Heart rate (HR) was calculated from R-R interval of ECG. STIs were recorded before and after intravenous (I.V.) administration of verapamil $(0.1 \mathrm{mg} / \mathrm{kg}$ body weight $)$. Electromechanical systole $\left(\mathrm{QS}_{2}\right)$, left ventricular ejection time (LVET), pre ejection period (PEP) and ratio of PEP LVET were calculated (Figure 1). To calculate STI indices, the values were corrected for HR using Weissler original HR STI regression. ${ }^{2}$

The data were subjected to statistical analysis using student ' $t$ ' test. $P$ values of less than 0.05 were taken as statistically significant.

\section{RESULT}

There was significant fall in mean arterial pressure and heart rate after administration of I.V. verapamil ( $\mathrm{p}<$ $0.001) . \mathrm{QS}_{2}$ showed reduction from $160 \pm 7.72$ to 
Table 1. Effect of verapamil on systolic time intervals

\begin{tabular}{llll}
\hline Parameter & Before & After & P value \\
\hline Heart rate (beats/min) & $273.33 \pm 4.84$ & $212.88 \pm 3.73$ & $<0.001$ \\
Mean arterial pressure (mmHg) & $87.42 \pm 1.15$ & $59.73 \pm 4.60$ & $<0.001$ \\
QS $_{2}$ (m sec.) & $160 \pm 17.72$ & $148.75 \pm 21.46$ & $<0.001$ \\
LVET (m sec.) & $87 \pm 21.38$ & $106.25 \pm 17.89$ & $<0.001$ \\
PEP (m sec.) & $71.11 \pm 23.68$ & $42.5 \pm 20.46$ & $<0.001$ \\
PEP/LVET (ratio) & $0.89 \pm 0.44$ & $0.26 \pm 0.08$ & $<0.001$ \\
\hline
\end{tabular}

$148.75 \pm 21.46(\mathrm{p}<0.001)$ after verapamil. There was significant rise in LVET and fall in PEP and ratio of PEP to LVET ( $\mathrm{p}<0.001$ ) from control values on verapamil administration (Figure 2 and Table 1 ).

\section{DISCUSSION}

STI is an indirect non-invasive measure of myocardial contractility. Effects of calcium antagonists result from a complex interplay of direct and indirect cardiac and vascular actions. Bradycardia after verapamil in present study may be a direct effect. It may be due to reduction in the frequency of sinoatrial (SA) depolarisation. ${ }^{1}$ Its direct effect on SA node is shown by the observation that after injection of verapamil into the SA nodal artery the heart rate decreases ${ }^{3}$ and autonomic blockade failed to eliminate this effect. ${ }^{4}$

Calcium blocking drugs interfere with electromechanical coupling in contractile tissues. ${ }^{1}$ This explains the reduction in $\mathrm{QS}_{2}$ in present communication. Prolongation of LVET, and indicator of contractility, indicates increase in stroke volume. ${ }^{5}$ But inspite of reduced $\mathrm{HR}$, LVET is found to be elevated in this study while the hemodynamic consequence of direct negative chronotropic effect is a potential decrease in cardiac output. So either a reduced HR with consequent increase in diastolic filling period or decrease in LV after load induced by vasodilatation (fall in $\mathrm{mAP}$ ) alone or baroreceptor mediated reflexes increase in betaadrenergic tone in response to vasodilation ${ }^{1}$ could increase the LEVT.

PEP and ratio of PEP/LVE are good measure of inotropic state of heart. ${ }^{6} \mathrm{PEP}$ has significant correlation with LV dp/dt. Decrease LV performance results in increase in PEP/LVET and PEP. It is reported that verapamil exert negative inotropic effect in isolated myocardial preparation. ${ }^{7}$ In the present context in- creased contratility as evident by decrease PEP and ratio of PEP/LVET can be explained by its indirect effect. That is baroreceptor mediated reflex increase in beta adrenergic tone elicited by peripheral vasodilatation after verapamil. Further, it increases the myocardial oxygen supply (coronary arterial vasodilatation) as well as reduces myocardial oxygen demand (reduced heart rate and after load). ${ }^{1}$

So, changes in STIs showed that verapamil enhances the contractile state of ventricle. This is in consistent with the findings of other authors who stated that a siginificant improvement in cardiac function was observed with increase in cardiac index and mean velocity of fiber shortening after administration of verapamil.

\section{REFERENCES}

1. Low RI, Takeda P, Mason DT, DeMaria AN. The effects of calcium channel blocking agents on cardiovascular function. Am J Cardiol 1982;49:537-53.

2. Weissler AM, Harris WS, Schoenfeld CD. Systolic time intervals in heart failure in man. Circulation 1968;37:14959.

3. Ono H, Himori N, Taira N. Chronotropic effects of coronary vasodilators as assessed in the isolated blood perfused sinoatrial preparation of the dog. Tohoku J Exp med 1977;121:383- 90.

4. Mangiardi LM, Hariman RJ, McAllister RG, Bhargava V, Suravicz B, Shebatai R. Electrophysiologic and hemodynamic effects of verapamil: correlation with plasma drug concentration. Circulation 1978;57:366-72.

5. Tavel ME. Clinical phono cardiography and external pulse recording. $3^{\text {rd }}$ ed. Year book medical publishers, Inc. Chicago, London 1978;193.

6. Weissler AM, Garrad CL Jr. Systolic time intervals in cardiac disease. Mod Contc Cardiovase Dis 1970;40:1.

7. Henry PD. Comparative pharmacology of calcium antagonists: nifedipine, verapamil; correlation with plasma drug concentrations. Am J Cardiol 1980;46:1047-58. 


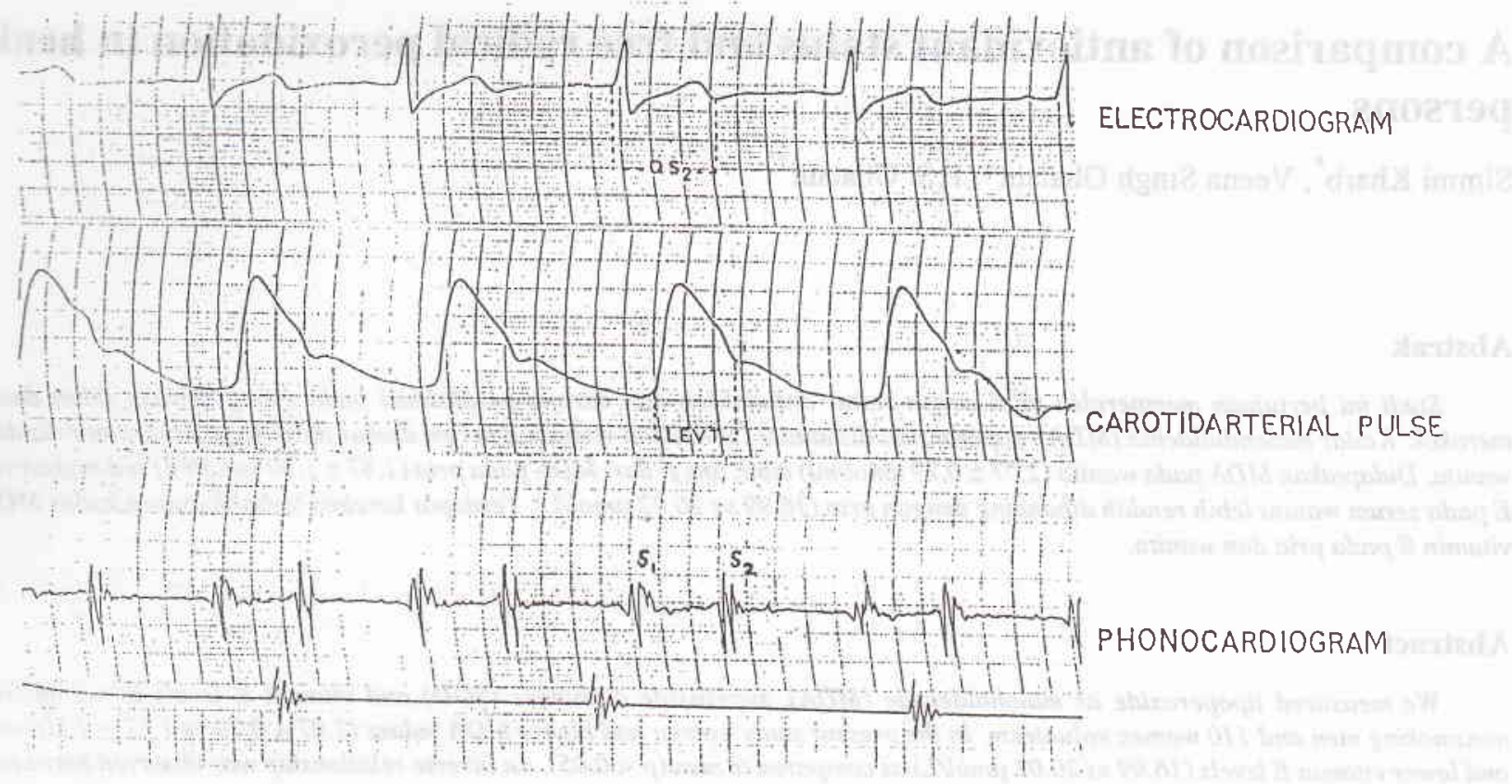

Figure 1. Simultaneous recording of ECG, CAP and PCG

QSE : electromechanical systole - measured from onset of QRS complex to the first high frequency vibration of $S_{2}$

LVET : left ventricular ejection time - measured from beginning of sudden upstroke to the through of the dicrotic notch of CAP

PEP : $\mathrm{QS}_{2}$ - LVET

$S_{1} \quad$ : first heart sound

$\mathrm{S}_{2} \quad$ : second heart sound

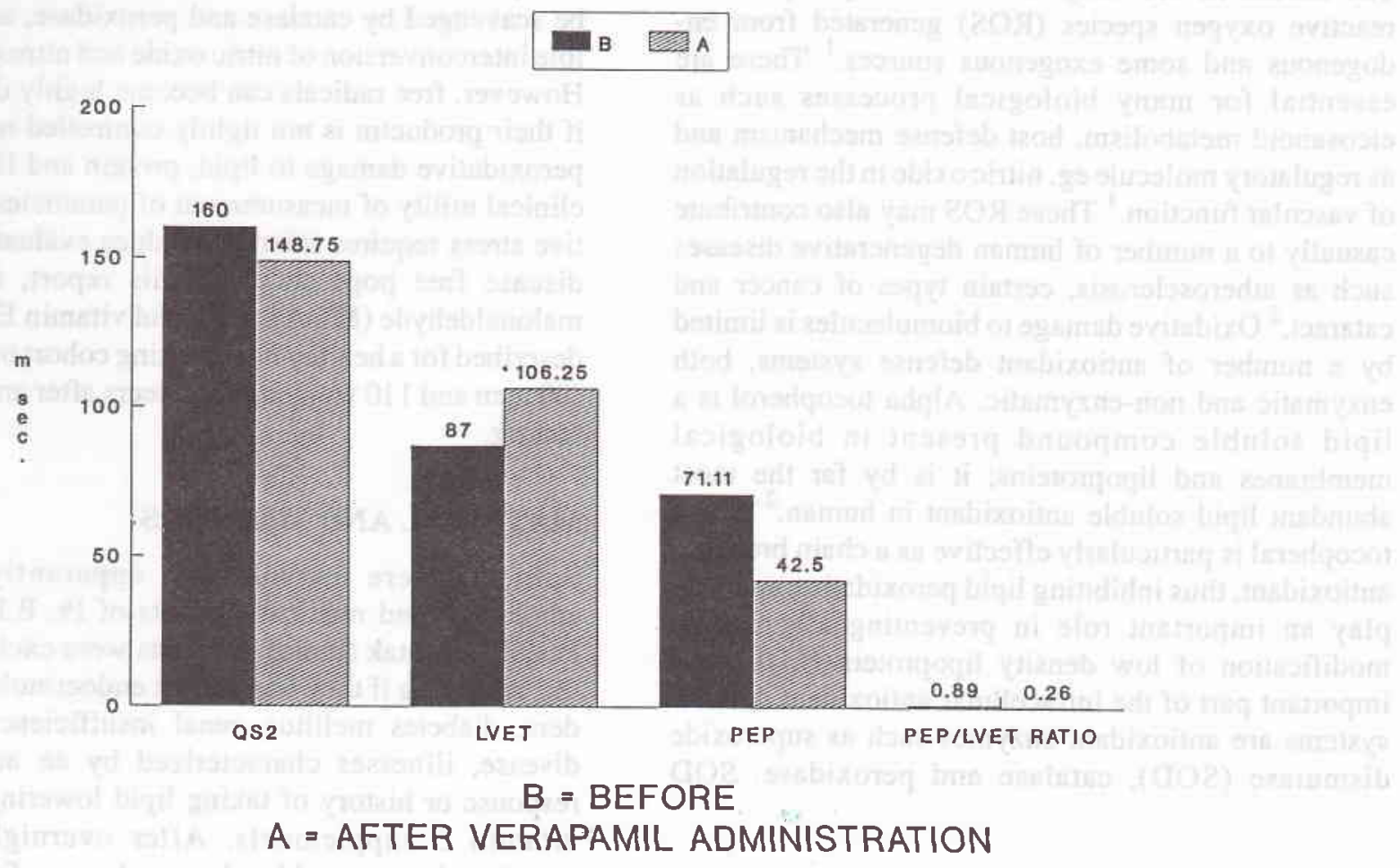

Figure 2. Effect of verapamil on STI 